NATIONALISM AND THE DRIVE FOR SOVEREIGNTY IN TATARSTAN, 1988-92 
This page intentionally left blank 


\section{Nationalism and the}

Drive for Sovereignty in Tatarstan, 1988-92

Origins and Development

Sergei Kondrashov

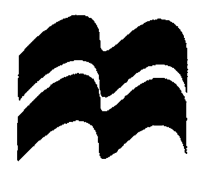


First published in Great Britain 2000 by

\section{MACMILLAN PRESS LTD}

Houndmills, Basingstoke, Hampshire RG21 6XS and London

Companies and representatives throughout the world

A catalogue record for this book is available from the British Library.

\section{ISBN 978-1-349-40753-8 ISBN 978-0-230-50366-3 (eBook)}

DOI $10.1057 / 9780230503663$

\section{First published in the United States of America 2000 by}

\section{ST. MARTIN'S PRESS, INC.,}

Scholarly and Reference Division,

175 Fifth Avenue, New York, N.Y. 10010

\section{Library of Congress Cataloging-in-Publication Data}

Kondrashov, Sergei, 1962-

Nationalism and the drive for sovereignty in Tatarstan, 1988-92 :

origins and development / Sergei Kondrashov.

p. $\mathrm{cm}$.

Includes bibliographical references and index.

1. Tatarstan (Russia) - Politics and government-20th century.

2. Nationalism-Russia (Federation)-Tatarstan. 3. Tatarstan

(Russia)-History-Autonomy and independence movements - 20th century. I. Title.

DK511.T17K66 1999

$320.54^{\prime} 0947^{\prime} 4509048-\mathrm{dc} 21$

(C) Sergei Kondrashov 2000

Softcover reprint of the hardcover 1st edition 2000 978-0-333-73376-9

All rights reserved. No reproduction, copy or transmission of this publication may be made without written permission.

No paragraph of this publication may be reproduced, copied or transmitted save with written permission or in accordance with the provisions of the Copyright, Designs and Patents Act 1988, or under the terms of any licence permitting limited copying issued by the Copyright Licensing Agency, 90 Tottenham Court Road, London W1P 0LP.

Any person who does any unauthorised act in relation to this publication may be liable to criminal prosecution and civil claims for damages.

The author has asserted his right to be identified as the author of this work in accordance with the Copyright, Designs and Patents Act 1988.

This book is printed on paper suitable for recycling and made from fully managed and sustained forest sources.

$\begin{array}{rrrrrrrrrr}10 & 9 & 8 & 7 & 6 & 5 & 4 & 3 & 2 & 1 \\ 09 & 08 & 07 & 06 & 05 & 04 & 03 & 02 & 01 & 00\end{array}$




\section{Contents}

List of Tables $\quad$ vi

List of Figures vii

Acknowledgements viii

Introduction ix

Map of Tatarstan xiii

1 Economic Modernisation in Tataria and its Impact on Social and Ethnic Stratification 1

2 Modernisation and the Problem of Ethnic Status in Tataria

3 Gorbachev's Perestroika, 1985-91, and the Collapse of the Legitimacy of the Soviet System

4 The Crisis of Legitimacy in Tataria and the Formulation of the Tatar Nationalist Project

5 The Strategy of Tatarstan's Political Establishment: The Politics of Stability

6 The Rise of the National Movement in Tataria: 1988-9 113

7 Tatarstan's Sovereignty Declaration

8 The Presidential Elections of 1991 in Tatarstan: The Growing Tensions between the Authorities and the Tatar National Movement

9 The Nationalists' Drive to Independence and the Victory of the Republican Establishment

10 Conclusion

Notes and References

Glossary

Bibliography 


\section{List of Tables}

1.1 The distribution of the urban population of Tataria by nationality according to the republican census of 1923

1.2 The distribution of the urban population of Tataria by nationality according to the USSR census of 1989 (republican cities and district centres only)

1.3 Distribution of the Tatars in the USSR and the RSFSR and their urbanisation levels according to the 1989 census

1.4 Occupation structure of the nationalities of the Volga region in the RSFSR according to the 1989 census

2.1 The distribution of the population of Tatarstan and the Middle Volga region by language and literacy according to the USSR census of 1926

2.2 Linguistic situation in Tatarstan according to the USSR census of 1989

5.1 Largest regions of the Russian Federation by population, 1991

5.2 Largest regions of the Russian Federation by industrial output, 1991

5.3 Largest regions of the Russian Federation by agricultural output, 1991

5.4 Largest regions of the Russian Federation by annual investments in fixed assets, 1991 


\section{List of Figures}

1.1 Dynamics of ethnic structure of Tatarstan 5

1.2 Urbanisation in Tatarstan 5

1.3 The ethnic structure of Tatarstan's urban and rural population, $1989 \quad 9$

1.4 The dynamics of urbanisation of the Russians and the Tatars in Tatarstan and in the Russian Federation

8.1 Popular support for Tatarstan's main political parties in Kazan' (April 1991) 


\section{Acknowledgements}

Many people have given me direct or indirect assistance in carrying out this research. However, it would never have been brought to a successful end had it not been for two people.

I am deeply indebted to Mr George Soros, for it was his project that gave me the opportunity to come to the United Kingdom and study at Manchester University. Later, once again it was his foundation that extended its generous help and made it possible for me to finish this study.

The second person whose assistance has been crucial for me is my supervisor Mr Chris Binns. Without fruitful discussions with him, without his advice and critical comments, without his support and encouragement this work would never have been accomplished, and I am very grateful to him for all the time and effort he has spent on me.

I am very thankful to Dr Yoram Gorlizky for all his assistance, especially for his helpful comments on the final version of my manuscript. I am also very much obliged to Dr Ursula Vogel and Dr Michael Moran who have made it possible for me to finish my study. I greatly appreciate the support of Manchester University, the Department of Government and the Overseas Research Students Awards Scheme who provided funding for my research. And finally, I wish to thank all the staff of the Department of Government of Manchester University - it has been a great pleasure to study and work amongst these wonderful people. 


\section{Introduction}

The rise of nationalism in the USSR in the late 1980s was clearly an unexpected phenomenon for mainstream Sovietologists. Even more unexpected for them was the rise of national movements in some ex-autonomous republics of the Russian Federation (RF). Traditionally, the bulk of attention of Western Sovietologists has always been drawn to the big nations of the ex-USSR. Very little was known about Russia's ethnic minorities, with the possible exception of the Jews. The small nations of the former autonomous republics have always been treated as cases of successful assimilation by the Russians and, therefore, nothing of interest was expected to be found there.

Tatarstan has been one of the most spectacular cases of this rise of nationalism in the late 1980s and early 1990s. Tatarstan - in the Soviet times better known as Tataria, the Russian equivalent of the name - is a republic situated in the basin of the Volga river, at the place where it meets its largest tributary, the Kama. By the size of its territory (some 26 thousand square miles) and population (a little under four million) it could be likened to the Republic of Ireland.

Tatarstan's population consists mainly of Tatars and Russians, with Chuvashes coming a distant third. The Tatars, an ethnic group of Turkic origin, are the largest ethnic minority group in Russia, comprising 3.8 per cent of the total population of the Russian Federation (RF) according to the 1989 census. The traditional religion of their overwhelming majority is Sunni Islam. They settle all over Russia and in most countries of the former Soviet Union. However, the majority of all the Tatars in Russia are concentrated in the Middle Volga: a little under a third of all the Tatars in the RF live in Tatarstan, about a fifth in neighbouring Bashkiria and about a tenth in other regions and republics surrounding Tatarstan.

Since the Gorbachev years Tatarstan has become an important player in Russian politics. The Tatar national movement that emerged in 1988 has been arguably amongst the strongest in the RF. Furthermore, Tatarstan has championed and spearheaded the drive of Russia's autonomous republics for sovereignty. In 1991-2 it even appeared that Tatarstan would make an attempt at staging a de-facto secession from the Russian Federation and fall victim to ethnic strife 
between Tatars and Russians. Yet within just two years Tatarstan came to be celebrated as the model for revamping Russia's federalism.

These developments seem to refute the old view of the Tatars in Tatarstan as a case of successful assimilation, and compel us to analyse ethnic processes in Tatarstan and their likely impact on Russia's political stability. The attitude of many Russian politicians to the Tatarstan way of resolving ethnic tensions and rebuilding federalism in the Russian Federation remains rather ambivalent. It is often looked at with suspicion and interpreted as the advancement of ethnic Tatar nationalism. Although at the moment the main attention is fastened upon the Caucasus, it is clear that given the economic and political influence of Tatarstan and the position of the Tatars as the second largest ethnic group in Russia, the role of this republic in the development of Russia's federalism will be fairly significant.

Until recently there have been just a handful of studies in the West that discuss the Tatars. Many of these studies have been written by emigres and are basically historical studies. ${ }^{1}$ This situation has begun to change. Between 1993 and 1995 Russian and Western ethno-sociologists carried out detailed research into nationalism in Russia which included an extensive study of Tatar nationalism. ${ }^{2}$

The present study is an attempt to analyse the origins of nationalism and the drive for sovereignty in Tatarstan. It deals with the period 1988 to 1992 which, in our view, represents a clearly defined page in the history of the Tatar national movement. This period was marked by the revival of Tatar nationalism and its desperate attempt to implement the vision of a Tatar nation state, which ended in apparent failure and a crisis in the movement. These years were also crucial for the shaping of the so-called 'Tatarstan model' of resolving tensions with Moscow and containing nationalism.

We shall address four major problems. To begin with, we shall explore the nature of the Tatars' grievances as they were shaped on the eve of perestroika, and examine what kind of nation the Tatars are. Our focus here will be on the effects of economic and cultural modernisation on the Tatars and the attitudes of Tatars and Russians towards each other. These are the issues of Chapters 1 and 2 .

We shall also explore why and how nationalism grew so strong, apparently out of the blue, in a republic generally believed in the West to have been successfully assimilated. In our view this sudden rise of nationalism is explained by the collapse of the legitimacy of the Soviet system. This is the subject of Chapter 3 . 
The problem of legitimacy is closely bound up with the issue of what replaced the 'collapsed communism'. Therefore, we shall examine the validity of the statement that the purported ideological vacuum which emerged after the 'collapse of communism' was filled by nationalists and nobody else. As we shall demonstrate in Chapter 4, in Tatarstan the 'nationalist' discourse took shape in debates with a 'democratic' discourse that emerged simultaneously.

We shall analyse also the extent to which the national ruling elite in Tatarstan espoused nationalism. In Chapter 5 we shall argue that while the republican political and economic establishment acknowledged the urgency of some grievances expressed by the Tatar national movement, during the period under consideration the ruling elite as a whole pushed for Tatarstan's sovereignty from considerations other than nationalistic ones.

Chapters 6 to 9 will give a brief outline of political developments in Tatarstan as they evolved in a struggle between three major political forces: the ruling elite (the establishment), the nationalists and the democrats. They will show the extent to which the nationalist discourse met with a response amongst the Tatars and will discuss the attitudes of the three forces towards sovereignty and the problems they encountered.

The terms 'nationalist' and 'democrat' are used in this study as self-styled labels adopted by the two political currents in Tataria. The name 'democrat' was in everyday use, and denoted people supporting radical political and economic reforms, generally associated first with the Democratic Russia movement and, from 1990, with Boris Yeltsin. This label spawned such variants as 'radical democrat', 'moderate democrat' and the like, but we avoid going into the differences between their various shades. Just as democrats themselves bore the name with pride, the nationalists used the term 'democrat' as a term of abuse.

The label 'nationalist' was comparatively less widespread. More often one comes across the label 'Tatar national movement'. However, activists of the national movement were at pains to exculpate the term 'nationalism' - for them it meant patriotism and defending national interests. The democrats, naturally, used the word 'nationalists' as a term of abuse. In fact, it was the name of the movement that stood for establishing a Tatar nation state in Tatarstan. Therefore, we shall follow this pattern and use the term 'nationalism' as the shorthand for 'Tatar national movement' to describe the movement aiming at building a Tatar nation state. As such, 
the terms 'democrats' and 'nationalists' are used in their neutral meaning. In this study we make great effort to enable the reader to look at political processes in Tatarstan through the eyes of their three main actors - the political establishment, the nationalists, and the democrats.

The study is based on the analysis of Tatarstan's republican press throughout the period under consideration, which represents the main source of primary data for us. Apart from this, we also draw upon Soviet ethno-sociological research conducted in Tatarstan in 1967, 1974-5, 1983 and 1989-90. ${ }^{3}$ The data of these ethno-sociological studies are used, however, to support our own conclusions, which in some important points are rather different from those made by the researchers themselves. Therefore, the present author is solely responsible for such a reformulation. 


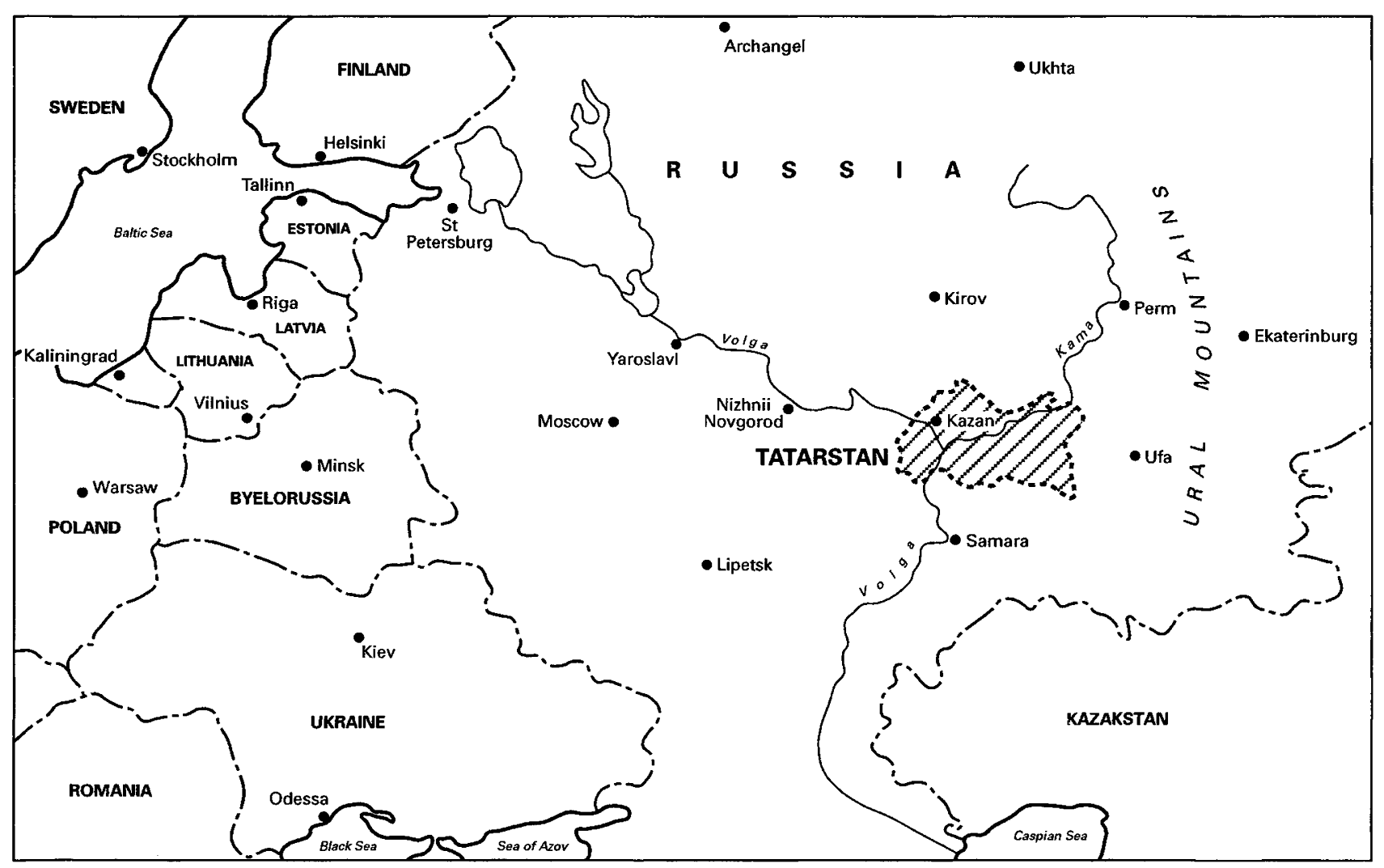

Location of Tatarstan 